\begin{tabular}{|c|c|c|}
\hline inst & $\begin{array}{l}\text { CARADDE: Jurnal Pengabdian Kepada Masyarakat } \\
\text { https://journal.ilininstitute.com/index.php/caradde } \\
\text { Volume 1 | Nomor 2 | Februari |2019 } \\
\text { e-ISSN: } 2621-7910 \text { dan p-ISSN: 2621-7961 } \\
\text { DOI: https://doi.org/10.31960/caradde.v1i2.35 }\end{array}$ & $\begin{array}{l}\text { TiN } \\
\text { CARADDE }\end{array}$ \\
\hline
\end{tabular}

\title{
Pelatihan Penyusunan Laporan Studi Kelayakan Kepada Masyarakat Bisnis Pada UMKM
}

\author{
Sulistya Rini Pratiwi ${ }^{1}$, Eko Prihartanto ${ }^{2}$, Meylin Rahmawati ${ }^{3}$, Said Usman ${ }^{4}$
}

\author{
Keywords : \\ UMKM; \\ Kompetensi; \\ Bisnis; \\ Laporan.
Corespondensi Author
${ }^{1}$ Ekonomi, Universitas Borneo
Tarakan
Jalan Amal Lama No.1 Kota
Tarakan
Email: miss.rainy@ymail.com

\section{History Artikel}

Received: Oktober-2018;

Reviewed: November-2018

Accepted: Desember-2018

Published: Februari-2019
Abstrak. Pemberdayaan Usaha Mikro Kecil Menengah (UMKM) sangat penting dan strategis dalam mengantisipasi kedudukan perekonomian kedepan terutama dalam memperkuat struktur perekonomian suatu daerah. Usaha Mikro Kecil Menengah (UMKM) sulit berkembang dikarenakan kompetensi pemilik usaha yang masih kurang dalam mengelola usaha, biasanya mereka berjalan apa adanya atau usaha turun temurun dari warisan orang tua, sehingga apabila dinilai perkembangan usaha mereka hanya terbatas menutupi kebutuhan hidup pemiliknya tanpa berusaha untuk mengembangkannya. Untuk keberhasilan tujuan dan sasaran kegiatan PKM ini maka dilakukan beberapa metode pendekatan seperti Identifikasi masalah, Survey Pendahuluan,. Evaluasi dan Laporan hasil. Berdasarkan hasil kegiatan diperoleh: 1) terdapat peningkatan pemahaman pentingnya pelaporan yang baik dan benar; 2) meningkatnya kemampuan dalam penyusunan laporan studi kelayakan proyek; 3) Mitra dapat mengetahui nilai hasil dari pengolahan pelaporan secara mandiri. Penyusunan Laporan Studi Kelayakan Usaha sangat diperlukan oleh Mitra untuk dapat menghindari dari resiko kerugian dengan melihat layak tidaknya suatu bisnis dilaksanakan secara terus menerus. Laporan Studi Kelayakan Usaha ini juga memudahkan Mitra untuk dapat melakukan perencanaan, pengawasan dan pengendalian usahanya.

\section{PENDAHULUAN}

Sektor usaha kecil dan menengah saat ini merupakan sektor yang sangat diperhatikan oleh pemerintah, hal ini terbukti dengan seriusnya perhatian pemerintah dalam mengembangkan Usaha Mikro Kecil Menengah (UMKM) di Indonesia. Hal ini dinilai wajar karena ternyata usaha kecil dan menengah sangat berpengaruh terhadap perekonomian negara, bahkan lebih dari separuh penduduk Indonesia berpenghasilan dari sektor ini.

Maith menjelaskan bahwa Laporan keuangan merupakan salah satu informasi yang sangat penting dalam menilai perkembangan perusahaan, dapat juga digunakan untuk menilai prestasi yang 
dicapai perusahaan pada saar lampau, sekarang dan rencana pada waktu yang akan datang (Maith 2013:620).

Laporan keuangan merupakan alat yang sangat penting untuk memperoleh informasi sehubungan dengan posisi keuangan dan hasil-hasil yang telah dicapai oleh perusahaan bersangkutan" (Munawir: 2013:31). Sedangkan menurut Kristanty (2017:5) Kinerja keuangan adalah suatu kegiatan yang dilakukan perusahaan dalam mengukur prestasi perusahaan dalam modal secara efektif dan efisien demi tercapaianya tujuan perusahaan.

Pemberdayaan Usaha Mikro Kecil Menengah (UMKM) sangat penting dan strategis dalam mengantisipasi kedudukan perekonomian kedepan terutama dalam memperkuat struktur perekonomian nasional. Adanya krisis perekonomian nasional seperti sekarang ini sangat mempengaruhi stabilitas nasional, ekonomi dan politik, yang imbasnya berdampak pada kegiatan-kegiatan usaha besar yang semakin terpuruk, sementara Usaha Mikro Kecil Menengah serta Koperasi relatif masih dapat mempertahankan kegiatan usahanya (Adam dkk, 2016). Ketika terjadi krisis ekonomi 1998, hanya sektor UMKM yang bertahan dari kolapsnya ekonomi, sementara sektor yang lebih besar justru tumbang oleh krisis. Krisis ini telah mengakibatkan kedudukan posisi pelaku sektor ekonomi berubah. Usaha besar satu persatu pailit karena bahan baku impor meningkat secara drastis, biaya cicilan utang meningkat sebagai akibat dari nilai tukar rupiah terhadap dollar yang menurun dan berfluktuasi (Hapsari, Hakim and Soeaidy, 2014). Sektor perbankan yang ikut terpuruk turut memperparah sektor industri dari sisi permodalan. Banyak perusahaan yang tidak mampu lagi meneruskan usaha karena tingkat bunga yang tinggi. Berbeda dengan UMKM yang sebagian besar tetap bertahan, bahkan cenderung bertambah (Departemen Koperasi, 2008).

\section{a) Mitra Usaha Mikro Bude Ram}

Pemilik Usaha Mikro Bude Ram adalah Ibu Siti Ramlah yang terletak diJl.Gunung Amal Rt 10 No 25 Kampung Enam Tarakan.Usaha ini didirikan sejak tahun 1982 dan bergerak pada bidang usaha makanan ringan.Jenis makanan ringan yang dihasilkan seperti madu mongso, krupuk, brownies dan kue tradisional lainnya. Usaha Mikro Bude Ram, saat ini telah memilki ijin usaha yang meliputi: (1) Sertifikat Produksi Pangan Industri Rumah Tangga dari Pemerintah Kota Tarakan Dinas Kesehatan (P-IRT NO. 2156473030050-19);

Sertifikat Halal dari Majelis Ulama Indonesia NO 10120007160415.

Produk olahan makanan ringan tersebut dijual dalam bentuk sudah siap saji dengan merek "Bude Ram". Dikemas dan dibuat dalam bentuk berbeda-beda. Untuk produk madu mongso, menggunakan bahan baku utama adalah beras ketan hitam, dengan bahan campuran buah durian, buah terap dan rumput laut. Madu mongso dikemas dengan berat 150 gram seharga Rp. 15.000,-.Produk krupuk memiliki bentuk yang beragam, yaitu bentuk pilus, stick, dan bentuk bulat. Bahan baku utama krupuk adalah, singkong, ubi ungu, dan tepung tapioka dengan bahan campuran rumput laut, ikan bandeng dan ikan bulan-bulan. Krupuk dikemas dengan berat 100 gram seharga Rp. 10.000,-. Untuk produk brownies dengan ukuran sedang dan besar, dibuat berdasarkan pesanan. Sedangkan dengan ukuran cup selalu dibuat setiap hari. Jenisnya beragam, yaitu brownies lapis, brownies singkong, brownies rumput laut, dll. Harga bervariasi, yaitu Rp.7.500/cup, Rp.25.000/ ukuran sedang, dan Rp. 50.000/ ukuran besar. Produk olahan lainnya yang diproduksi oleh UMKM Bude Ram adalah kue tradisional. Kue tradisional yang diolah bermacammacam, yaitu Kue Bikang, Kue Lumpur, Kue Mangkok, dan lain-lain. Harga kue tradisional ini berkisar Rp.2.500,- sampai Rp.12.000,--.

Mitra UMKM dalam hal ini Bude Ram dan Amplang Tari belum memliki kemampuan dalam menyusun Laporan Studi Kelayakan Usaha. Penyusunan Laporan Studi Kelayakan Usaha sangat diperlukan oleh Mitra untuk dapat menghindari dari resiko kerugian dengan melihat layak tidaknya suatu bisnis dilaksanakan secara terus menerus. 
Laporan Studi Kelayakan Usaha ini juga memudahkan Mitra untuk dapat melakukan perencanaan, pengawasan dan pengendalian usahanya.

Mengingat bahwa kondisi dimasa yang akan datang dipenuhi oleh ketidakpastian, maka diperlukan pertimbangan-pertimbangan tertentu, karena itu dalam Laporan Studi Kelayakan Usaha terdapat berbagai aspek yang harus dikaji dan diteliti kelayakannya sehingga hasil dari laporan tersebut dapat digunakan untuk memutuskan apakah sebaiknya proyek atau bisnis layak dikerjakan atau ditunda atau bahkan dibatalkan.

\section{b) Mitra Usaha Mikro Amplang Tari}

Selanjutnya pemilik Usaha Mikro Amplang Tari adalah Ibu Sukarti yang terletak di Kampung Empat Rt.4 Gang Rambai 2, Kecamatan Tarakan Timur. Usaha ini didirikan sejak tahun 2011 dan bergerak pada bidang usaha makanan ringan olahan ikan, yaitu amplang. Usaha Mikro Amplang Tari, saat ini telah memilki ijin usaha yang dimiliki baru Sertifikat Produksi Pangan Industri Rumah Tangga dari Pemerintah Kota Tarakan Dinas Kesehatan (P-IRT NO. 2026473010078-20). Upaya label dari MUI Halal dan BPPOM masih dalam proses.

Bahan baku utama keseluruhan produk tersebut adalah olahan ikan, tepung dan bumbu-bumbu. Produk ola ha n ik a n tersebut dijual dalam bentuk kemasan siap saji, dengan merek "Amplang Tari" yang dikemas dengan berat bervariasi. Untuk amplang ikan bandeng per 500 gram seharga Rp.15.000,- sedangkan untuk per 200 gram amplang ikan tenggiri seharga Rp.10.000,-.

Dari aspek produksi usaha mikro Amplang Tari menggunakan bahan utama yang digunakan ikan bandeng dan ikan tenggiri hasil produksi tambak yang ada disekitar usaha (Kelurahan Pantai Amal). Kondisi ikan dan rumput laut masih segar dan harganya relatif murah. Untuk tenaga kerja banyak menggunakan tenaga ibu rumah tangga sekitar, sehingga tenaga kerja yang dibutuhkan mudah direkrut. Hal ini juga relevan dengan program pemerintah yakni untuk memberdayakan ekonomi kerakyatan dengan lebih mengutamakan sumber daya lokal.

Berdasarkan uraian di atas usaha mikro Amplang Tari menghadapi masalah sistem pembukuan atau pelaporan yang belum sesuai standar.

\section{c) Permasalahan Prioritas pada Mitra}

Berdasarkan analisis situasi ada beberapa permasalahan pada kedua mitra yang diusulkan dalam kegiatan PKM ini antara lain :

Masalah yang paling prioritas adalah Mitra UMKM dalam hal ini Bude Ram dan Amplang Tari belum memliki kemampuan dalam menyusun Laporan Studi Kelayakan Usaha. Penyusunan Laporan Studi Kelayakan Usaha sangat diperlukan oleh Mitra untuk dapat menghindari dari resiko kerugian dengan melihat layak tidaknya suatu bisnis dilaksanakan secara terus menerus. Laporan Studi Kelayakan Usaha ini juga memudahkan Mitra untuk dapat melakukan perencanaan, pengawasan dan pengendalian usahanya. (Hasil Wawancara dan Diskusi dengan Mitra)

\section{METODE}

Kegiatan Awal yang akan dilaksanakan adalah pelatihan dan pendampingan adalah Mengetahui variabel dalam pelaporan keuangan, dimana variabel ini didapat untuk menjadi bahan dalam pelatihan yang akan dilakukan setelah itu Mengetahui variabel dalam membuat laporan kelayakan usaha untuk mempersiapkan pelatihan sebagai penyusunan variabel untuk penerapan kepada mitra. Tahap selanjutnya adalah bagaimana Cara membuat laporan kelayakan usaha, hal ini dilakukan untuk melihat progress dari pelatihan terhadap mitra, sejauhnya tingkat pemahaman mitra terhadap pelaporan keuangan tersebut.

Adapun Manfaat yang diperoleh mitra dari pelaksanaan kegiatan tersebut adalah, Mitra dapat mengetahui variabel dalam penyusunan pelaporan kelayakan usaha sehingga Mitra dapat membedakan laporan keuangan dan pelaporan 
kelayakan usaha Secara mandiri selain itu Mitra juga dapat mengetahui nilai hasil dari pengolahan pelaporan secara mandiri.

Kegiatan Program PKM ini dilaksanakan dengan beberapa tahapan sebagai berikut :

1. Tahap Persiapan, Pada tahap persiapan mengumpulkan bahan-bahan untuk pendukung pelatihan yang mana akan dibutuhkan adalah variabel-variabel penyusun laporan dari Mitra. Dari variabel tersebut akan disusun informasi yang akan dipilih dan dipindahkan menjadi bagian dalam bentuk pelaporan.

2. Tahap Pelaksanaan, adalah tahap pelaksanaan dari program pengabdian ini yaitu bagaimana menyusun pelaporan keuangan yang baik dan benar serta tertib administrasi, dalam tahap ini juga akan dilatih bagaimana membuat pelaporan kelayakan usaha yang baik dan benar sehingga dapat memberikan informasi bagi mitra apakah usaha tersebut layak untuk dilanjutkan atau dilakukan evaluasi.

3. Tahap Pendampingan, Pada tahap ini dilakukan setelah mitra menyusun laporan keuangan dan laporan kelayakan usaha, dimana para instruktur akan mengevaluasi berdasarkan data-data dari Mitra apakah telah sesuai dengan kaidah pelaporan atau belum memenuhi. Dan apabila belum memenuhi dalam penyusunan akan terus didampingi sampai laporan dapat dikatakan selesai dengan benar.

4. Tahap Evaluasi, Tahap ini dilakukan setelah semua tahap telah dilakukan, tujuannya adalah terpenuhimya kompetensi pada mitra sesuai dengan program pengabdian kepada masyarakat ini.

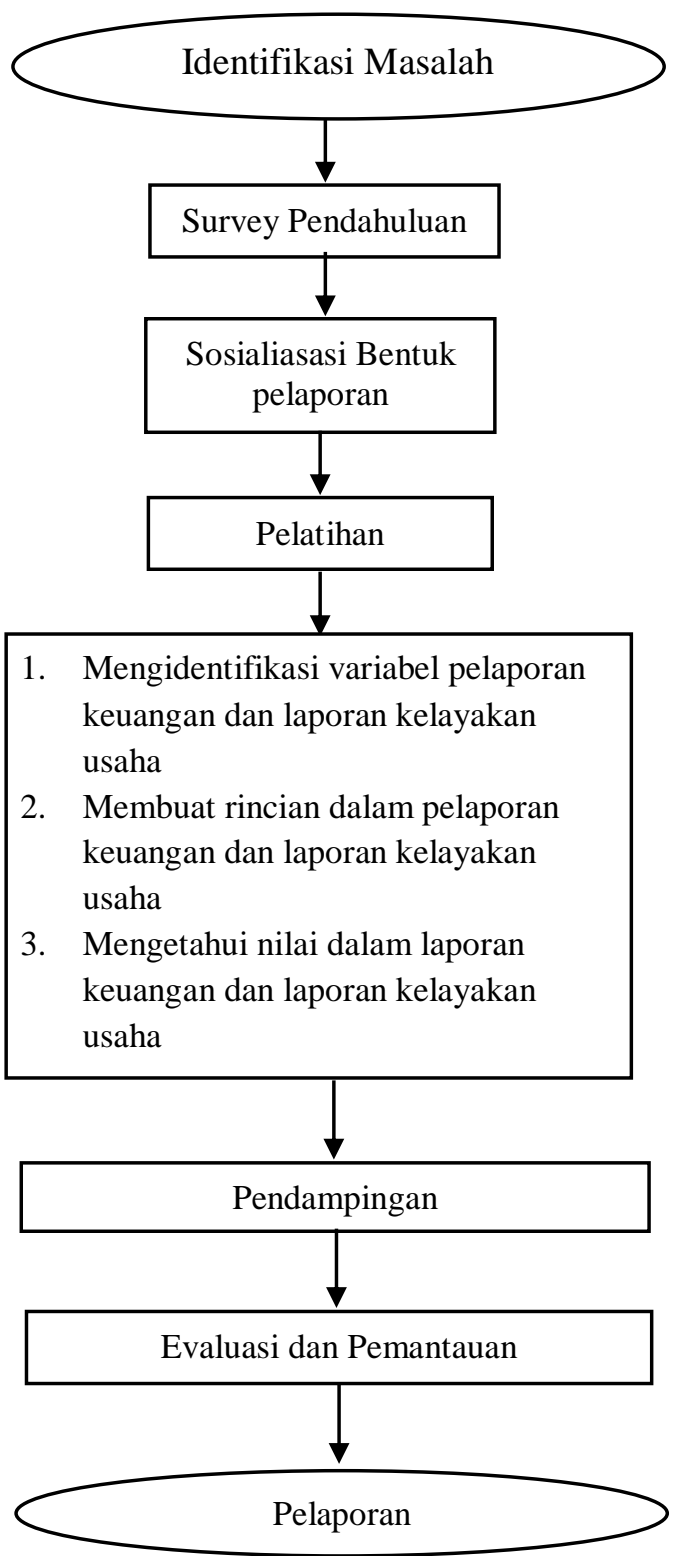

Gambar. 1 Diagram Alir Pelaksanaan

Kegiatan PKM ini diawali dengan melakukan kunjungan ke lokasi mitra. Kemudian melakukan wawancara dengan mitra. Setelah semua informasi tentang mitra diperoleh maka dilakukanlah diskusi atas perencanaan model awal produk dan akhir produk yang diikuti dengan implementasi dan evaluasi.

\section{HASIL DAN PEMBAHASAN}

Pelatihan dilaksanakan selama 12 kali pertemuan, dimulai dari 9 Juli - 13 Agustus 2018, bertempat di masing-masing UMKM mitra, yaitu di UKM Bude Ram di Gunung 
Amal Kampung Enam dan UKM Amplang Tari di Kampung Empat. Jumlah peserta yang mengikuti di masing-masing mitra yaitu 2 orang. Kedua peserta ini sebagai perwakilan setiap mitra. Namun di beberapa kesempatan, peserta menjadi lebih banyak, disesuaikan dengan kondisi tenaga kerja mitra pada saat kegiatan. Tujuan utama dilaksanakannya pelatihan dan pendampingan penyusunan laporan studi kelayakan usaha, yaitu Mitra dapat mengetahui variabel dalam penyusunan pelaporan kelayakan usaha, sehingga Mitra dapat membedakan laporan keuangan dan pelaporan kelayakan usaha Secara mandiri disamping itu Mitra dapat mengetahui nilai hasil dari pengolahan pelaporan secara mandiri

Pelatihan dilaksanakan selama kurang lebih 3 jam per pertemuannya. Adapun hasil Kegiatan utama yang dilakukan dalam pelatihan adalah Sharing permasalahan yang dihadapi mitra dalam berkegiatan, Bersamasama identifikasi variabel laporan kelayakan usaha. Membuat rincian dalam pelaporan keuangan dan laporan kelayakan usaha,
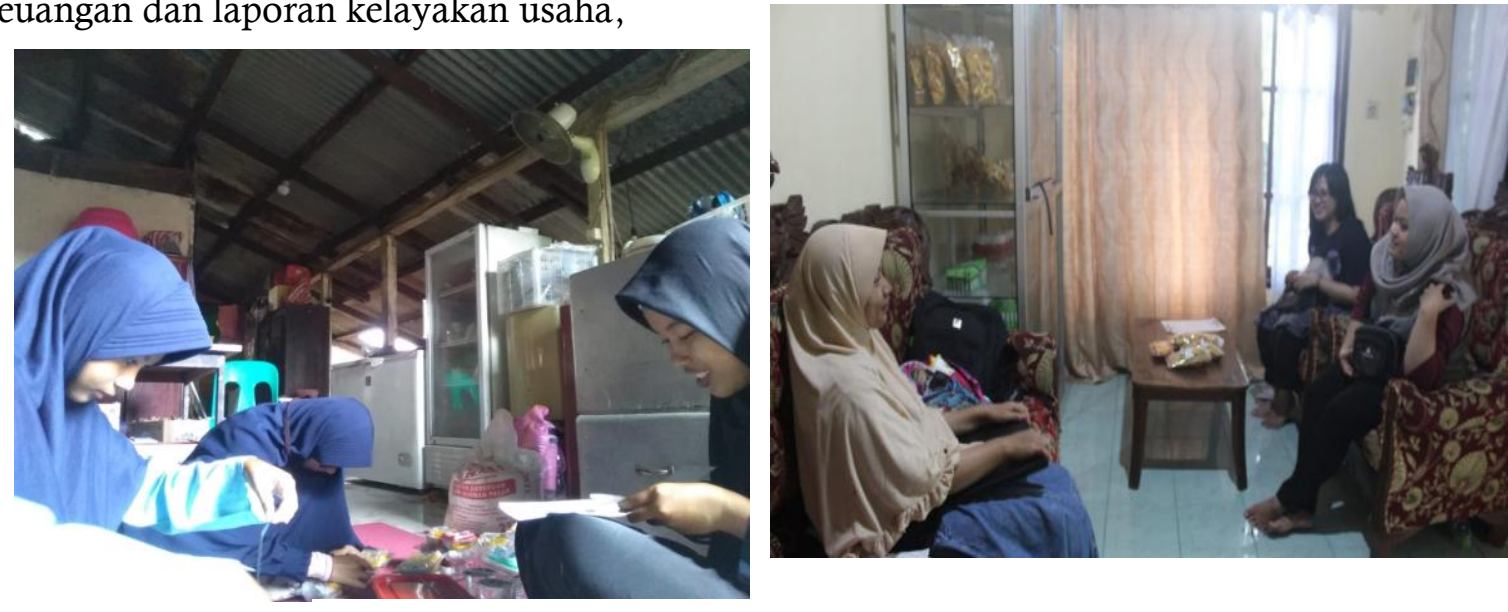

Gambar 2 Kegiatan Sosialisasi dan Pengumpulan data

Mengetahui nilai dalam laporan keuangan dan laporan kelayakan

Langkah awal sebelum mitra mempratekkan penyusunan laporan kelayakan, mitra diajak untuk memahami proses bisnis dari masing-masing kegiatan mitra. Kegiatan ini dilakukan pada saat sosialiasi dan pengumpulan data. Kegiatan ini dihadiri tim dan mitra, di lokasi masingmasing mitra.

Penekanan kegiatan ini adalah mengetahui secara detail alur dari proses penyusunan laporan kelayakan usaha. Mengidentifikasi varibale-variabel yang dibutuhkan. Adapun materi yang diberikan adalah sebagai berikut: (a) Aspek-aspek kelayakan usaha; (b) Pentingnya kelayakan usaha; (c) Pengertian kelayakan usaha; (d) Kerangka kelayakan usaha; (e) Bentuk formal kelayakan usaha; (f) Praktek mandiri pembuatan rencana usaha; (g) Evaluasi hasil perencanaan usaha dan tanya jawab pengelolaan usaha

Media pelatihan yang digunakan adalah laptop dan print out materi. Dengan metode ceramah dan tanya jawab.

Berikut hasil pengamatan selama kegiatan pendampingan.

a. Semua peserta dapat mengikuti seluruh proses pelatihan dari awal sampai selesai, kegiatan yang dirancang $100 \%$ terlaksana, dan kehadiran narasumber $100 \%$.

b. Target penyampaian materi pelatihan juga tercapai karena materi dapat disampaikan secara keseluruhan dan antusiasme peserta dalam mengikuti pelatihan sangat mendukung kegiatan ini

dievaluasi melalui praktek mandiri
penyusunan perencanaan usaha dan
pengelolaan usaha yang dilakukan.

Sehingga dari kegiatan ini sesuai dengan pernyataan dimana Proses implementasi merupakan hasil akhir dari pembukuan yang dilakukan, dalam hal ini berupa laporan keuangan. Pada usaha kecil sangat memerlukan informasi kinerja tentang laba/rugi usaha serta informasi posisi keuangan yaitu harta, kewajiban dan modal usaha (Musmini, 2013).

\section{SIMPULAN DAN SARAN}


Hasil kegiatan ini adalah peningkatan pemahaman mitra dalam proses pelaporan kelayakan bisnis, sehingga mitra mampu mengembangkan bussines plan yang telah disusun. Mitra terlihat antusias mempelajari buku panduan dan mempraktekkan penyusunan laporan. Laporan kelayakan memberikan gambaran nilai usaha dan kemudahan mitra dalam melakukan proses kegiatan dalam mendapatkan dana pinjaman usaha. Dari kegiatan ini peningkatan dalam persentasi setelah mendapatkan pemahaman sebesar $35 \%$ dimana mitra telah dapat mengontrol keuangan yang sebelumnya tidak tercatat menjadi tercatat.

Saran yang dapat disampaikan berdasar evaluasi kegiatan adalah melakukan kegiatan pendampingan berkala: (1) Mitra berharap tim bersedia untuk meluangkan waktu mendampingi di tahun berikutnya; (2) Selain itu, aspek teknis yang mapan harus diikuti dengan aspek keuangan yang baik. Sehingga kedepannya perlu dilakukan kegiatan pelatihan dan pendampingan penyusuran administrasi keuangan. Dari kegiatan ini peningkatan dalam persentasi setelah mendapatkan pemahaman sebesar 35\% dimana mitra telah dapat mengontrol keuangan.

\section{DAFTAR RUJUKAN}

Adam, Syarifuddin M, dkk. 2016. Pemberdayaan Usaha Mikro, Kecil, dan Menengah Kota Ternate (Studi Dinas Koperasi dan UKM Kota Ternate). Jurnallimu Sosial \& Pengelolaan Sumber daya Pembangunan, edisi XXI (MaretApril),hal 129-142.

De Groot, S., Rijnsburger, A. J., Versteegh, M. M., Heymans, J. M., Kleijnen, S., Redekop, W. K., \& Verstijnen, I. M. 2015. Which factors may determine the necessary and feasible type of effectiveness evidence? A mixed methods approach to develop an instrument to help coverage decisionmakers. BMJ Open, 5(7), e007241. http://doi.org/10.1136/bmjopen2014-007241. Tanggal diakses 23 Maret 2018.
Departemen Koperasi. 2008. PDB, Investasi, Tenaga Kerja, Nilai Ekspor UKM di Indonesia. Depkop. Jakarta. Kasmir. 2017. Studi Kelayakan Bisnis. Edisi Revisi. Prenada Media. Jakarta.

Hapsari, P. P., Hakim, A. and Soeaidy, S. (2014) 'Pengaruh Pertumbuhan Usaha Kecil Menengah ( UKM ) terhadap Pertumbuhan Ekonomi Daerah ( Studi di Pemerintah Kota Batu )', WACANA, 17(2), pp. 88-96.

Kasmir. 2013. Analisa LAporan Keuangan. Jakarta: Rajawali Pers.

Kesuma., Y. F. 2014. Analisis Laporan Keuangan Sebagai Dasar Dalam Penilaian Kinerja Keuangan PT. Budi Satria Wahana Motor. Jurnal Akuntansi dan Keuangan. Vol 5 No.1 Hal 93-121.

Kristanty., E. Y. 2017. Analisis Laporan Keuangan Untuk Mengukur Kinerja Keuangan Pada Perusahaan Farmasi yang Go Publik. Jurnal Ilmu dan Riset Manajemen. Vol 6 No 3. Hal 116.

Maith., H. A. 2013. Analisis Laporan Keuangan Dalam Mengukur Kinerja Keuangan Pada PT Hanjaya Mandala Sampurna TBK. Jurnal EMBA. Vol 1 No 3. Hal 619-628

Munawir. 2013. Analisa Laporan Keuangan. Liberty. Yogyakarta.

Mulyani, U., Yusmini, dan Edwina S. 2016. Analisis Kelayakan Finansial Usaha Agroindustri Tahu (Studi Kasus Agroindustri Tahu Bapak Warijan di Desa Rambah Muda Kecamatan Rambah Hilir Kabupaten Rokan Hulu). Jom Faperta Vol. 3 No. 1 Februari 2016.

Musmini, L. S. (2013) 'Sistem Informasi Akuntansi Untuk Menunjang Pemberdayaan Pengelolaan Usaha Kecil (Studi Kasus Pada Rumah Makan Taliwang Singaraja)', Jurnal Riset Akuntansi, 2(1), pp. 62-81.

Sudaryanto, dan A. Hanim. 2002. "Evaluasi kesiapan UKM Menyongsong Pasar Bebas Asean (AFTA) : Analisis Perspektif dan Tinjauan Teoritis. ". 
Pratiwi, Prihartanto, Rahmawati, Usman. Pelatihan Penyusunan Laporan

Jurnal Ekonomi Akuntansi dan

Manajemen,, Vol. 1, No. 2.

Sutrisno. 2013. Manajemen Keuangan :

Teori Konsep \& Aplikasi. Ekonesia.

Yogyakarta. 